\title{
STUDI IMPLEMENTASI KONSEP HALAL SUPPLY CHAIN PADA PASOKAN DAGING AYAM DI PASAR BARU KARAWANG
}

\begin{abstract}
Afif Hakim
afif.hakim@ubpkarawang.ac.id

Nama lengkap Intansi Penulis Teknik Industri, Fakultas Teknik dan Ilmu Komputer Universitas Buana Perjuangan Karawang afif.hakim@ubpkarawang.ac.id

ABSTRAK

Salah satu produk yang dekat dengan masyarakat dan selalu diminati untuk dikonsumsi adalah daging ayam. Oleh karena itu, diperlukan penelitian yang mengkaji mengenai kehalalan daging ayam curah dalam serangkain proses suplly chain-nya dari hulu ke hilir. Penelitian ini mengambil objek yaitu daging ayam yang dijual di Pasar Baru Karawang. Adapun kesimpulan yang dapat ditarik dari penelitian ini adalah ketiga pemasok daging ayam ke pasar baru karawang secara umum berdasarkan observasi secara langsung di lapangan sudah memenuhi syarat syar'i mengenai kehalalan daging ayam dan sampai kepada konsumen akhir tidak terkontaminasi dengan barang haram/najis. Akan tetapi tetap masih diperlukan penyempurnaan sebagai yaitu perlu dipastikan kembali kehalalan bahan dari makanan, minuman, vaksin, dan vitamin yang digunakan, perlu adanya pemastian menghadap kiblat, perlu adanya pemastian bahwa ayam yang disembelih sudah betul-betul mati sebelum proses selanjutnya atau minimal menunggu 3 menit.

Risiko yang dapat terjadi dikelompokkan menjadi resiko rendah, resiko sedang dan resiko tinggi. Risiko rendah yaitu daging ayam tercampur dengan bahan najis/haram dan timbangan tidak sesuai. Resiko sedang yaitu penyembelihan tidak menghadap kiblat. Sedangkan resiko tinggi yaitu ayam belum benar-benar mati karena berhubungan langsung dengan kehalalan daging ayam. Hal ini pula yang jarang disadari oleh para pemasok daging ayam mereka kebanyakan tidak memastikan benar-benar mati atau tidak menunggu setidaknya 3 menit. Oleh karena itu, dibutuhkan edukasi, standarisasi, serta kalibrasi timbangan.
\end{abstract}

Kata kunci : supply chain, kehalalan, haram, Pasar Baru Karawang 


\begin{abstract}
One of the products that are close to the community and always in demand for consumption is chicken. Therefore, it is necessary to study the halal chicken meat in the supply chain process from upstream to downstream. This research took the object, namely chicken meat sold in Pasar Baru Karawang. The conclusions that can be drawn from this study are that the three suppliers of chicken meat to the Karawang new market in general, based on direct observations in the field, have met the syar'i requirements regarding the halalness of chicken meat and until the end consumers are not contaminated with haram / najis goods. However, improvements are still needed as it is necessary to re-confirm the halalness of the ingredients of the food, drinks, vaccines, and vitamins used, it is necessary to ensure facing the Qibla, it is necessary to ensure that the slaughtered chickens have really died before the next process or at least wait 3 minute.

The risks that can occur are grouped into low risk, medium risk and high risk. Low risk, namely the chicken meat is mixed with unclean / haram ingredients and the scale is not suitable. The risk is moderate, namely the slaughter does not face the Qibla. Meanwhile, the high risk is that the chicken has not really died because it is directly related to the halal meat of the chicken. It is also something that is rarely realized by most of their chicken meat suppliers who do not ensure that they are really dead or do not wait at least 3 minutes. Therefore, it takes education, standardization, and scale calibration.
\end{abstract}

Keyword : supply chain, halal, haram, Pasar Baru Karawang (traditional market) 


\section{PENDAHULUAN}

Indonesia merupakan penduduk dengan jumlah muslim terbanyak di dunia. Berdasarkandata BPS pada Sensus Penduduk tahun 2010 bahwa penduduk yang beragama islam di Indonesiaadalah sebanyak 87,18\% dari 237.641.326 penduduk Indonesia. Dengan jumlah pendudukmuslim yang mendominasi tersebut, seharusnya pemerintah dapat menjamin kehalalan produkkonsumsi bukan hanya pada aspek secara fisik produknya saja, tetapi juga dari seluruh aspekrantai pasoknya sampai dengan produk tersebut dikonsumsi oleh masyarakat. Halal sendirimenurut Dahlan (1996) dalam buku Ensiklopedi Hukum Islam mendefinisikan halal adalah segalasesuatu yang menyebabkan seseorang tidak dihukum jika menggunakannya, atau sesuatu yangbolehdikerjakan

menurutsyara'.Olehkarenaitu,kehalalanataubolehnyamengkonsumsi/memakai suatu produk menurut syara' merupakan hal yang prinsip bagi umatislam dalam menjalankan agamanya. Disamping halal produk yang dikonsumsi juga harus sucidari najis dan juga dalam kondisi baik (thoyyiban).

Di Indonesia, sejak tahun 1989 sudah ada lembaga yang menangani sertifikasi halal yaituLembaga Pengkajian Pangan, Obat-obatan, dan Kosmetika Majlis Ulama Indonesia (LPPOMMUI). Pada perkembangannya, pada tahun 20172 dibentuk lembaga di bawah KementrianAgama yang dibentuk oleh UndangUndang No 33 Tahun 2014 dengan tugas menangani danmenjamin kehalalan produk yang beredar di masyarakat yaitu Badan Penyelenggara JaminanProduk Halal (BPJPH). Sehingga sejak tahun 2017, sertifikasi halal tidak pada LPPOM MUI lagi tetapi berpindah kepada BPJPH, namun MUI masih berperan dan diberi kewenangan dalam memberikan fatwa halal setelah proses pengecekan oleh BPJPH. Karena dibentuk oleh UndangUndang, maka BPJPH mempunyai legalitas dan wewenang yang kuat dalam mengembangkan dan meningkatkan jaminan kehalalan produk konsumsi kepada masyarakat. Akan tetapi jika ditelisik lebih jauh, sertifikasi halal yang diterbitkan oleh BPJPH hanya menitikberatkan pada bahan, proses, fasilitas produksi, dan produknya itu sendiri, tidak sampai kepada bagaimana distribusi sampai dikonsumsi atau dipakai oleh masyarakat. Padahal bisa saja produk yang secara dzati sudah mempunyai sertifikat halal, akan tetapi pada proses distribusi berikutnya sebelum sampai kepada pengguna akhir, produk tersebut tekontaminasi dengan barang-barang haram atau paling tidak dengan barang-barang yang tidak baik bahkan membahayakan untuk dikonsumsi. Hal tersebut menunjukkan betapa pentingnya "kehalalan" jalur distribusi sampai dengan pemakai akhir (end user). Di Indonesia, sampai dengan hari ini belum ada undangundang ataupun aturan yang menjamin kehalalan proses distribusi atau logistik barang. 
Salah satu produk yang dekat dengan masyarakat dan selalu diminati untuk dikonsumsi adalah daging ayam. Menurut data Organisation for Economic Cooperation and Development (OECD) yang dirilis pada 2018, dibandingkan dengan konsumsi daging sapi, masyarakat Indonesia lebih banyak mengkonsumsi daging ayam dengan rata-rata $7 \mathrm{~kg}$ daging per tahun. Meskipun angka ini lebih rendah dibandingkan Negara-negara lain di Asean. Oleh karenanya, sangat penting sekali jaminan halal terhadap produk daging ayam tersebut tersebut. Daging ayam yang dijual di Supermarket besar bisa saja sudah mempunyai sertifikat Halal walau tidak ada jaminan pada proses distribusinya. Sedangkan produk daging ayam curah yang ada di pasar tradisional hampir dipastikan tidak mempunyai sertifikat halal secara dzati apalagi yang berkaitan dengan proses distribusinya. Oleh karena itu, sangat diperlukan penelitian yang mengkaji mengenai kehalalan daging ayam curah dalam serangkain proses suplly chain-nya dari hulu ke hilir. Penelitian ini mengambil objek yaitu daging ayam yang dijual di Pasar Baru Karawang.

Menurut Tieman (2012), Halal Supply Chain adalah pengelolaan jaringan halal dengan tujuan untuk memperluas integritas halal dari sumber awal sampai ke titik pembelian konsumen. BahrudinIllyas \& Desa (2011) menjelaskan Halal manajemen rantai pasok adalah sebagai proses pengelolaan pengadaan, gerakan, penyimpanan dan penanganan bahan, bagian, ternak dan setengah jadi persediaan, makanan dan nonmakanan, dan informasi terkait bersama-sama dengandokumentasi mengalir melalui organisasi yang sesuai dengan umum prinsip-prinsip Hukum syariah.

\section{METODE PENELITIAN}

\section{Objek Penelitian}

Objek penelitian yang akan dibahas dalam penelitian ini adalah sistem rantai pasok pada perdagangan daging ayam di Pasar Baru Karawang yang meliputi pemasok, penjual di pasar, dan pembeli.

\section{Pengumpulan Data}

Teknik pengumpulan data adalah dengan cara observasi secara langsung di pasar baru Karawang, serta tempat pemotongan hewan, dan tempat-tempat lain yang ada kaitannya dengan penelitian ini. Selain itu pula, teknik wawancara dengan para responden terkait dan juga studi literature/pustaka yang berkaitan dengan hukum halal dalam islam. Jenis data pada penelitian ini 
adalah data primer yang berasal dari hasil observasi di lapangan dan hasil wawancara dengan responden. Selain itu pula, diperlukan data-data sekunder seperti data statistik Pasar Baru.

\section{Analisis Data}

Analisis yang digunakan adalah dengan metode kualitatif deskriptif dengan tahapan sebagai berikut :

1. Mengobservasi kondisi real di lapangan kemudian mencatat dengan sebaik-baiknya lalu membandingkan bandingkan dengan literature halal dalam agama islam dan menggali apakah sesuai atau tidak sesuai dan bagaimana seharusnya yang dilakukan. Literatur dimaksud telah dirumuskan dalam SNI 99001:2016 tentang Sistem Manajemen Halal dan SNI 99002:2016 tentang Pemotongan Halal pada Unggas.

2. Mencatat dan memetakan hal-hal yang berpotensi terjadinya pelanggaran, penyelisihan terhadap hukum syara' seperti misalnya bercampur dengan barang yang najis

\section{Kerangka Pemikiran}

Penelitian di bidang halal supply chain hingga saat ini semakin menunjukkan perkembangan dari berbagai isu dan area. Qurtubi (2018) menyatakan bahwa kajian mengenai halal logistic dan halal supply chain telah berkembang dan masih ada banyak peluang untuk untuk dikaji lebih lanjut baik secara empirik maupun teoritis mengingat hingga saat ini penelitian di bidang tersebut masih sangat terbatas. Beberapa peneliti lain diantaranya, Talib dkk (2015)melakukan kajian yang berjudul "Halal supply chain critical success factors: A literature review" menyimpulkan bahwa salah satu hal critical yang harus ada untuk mendukung upaya Standarisai Halal Suplly Chain adalah dukungan Pemerintah, perencanaan transportasi, teknologi informasi, manajemen sumber daya manusia, hubungan kolaborasi, sertifikasi halal dan halal traceability.

\section{HASIL PENELITIAN DANPEMBAHASAN}

\section{Analisis Kondisi}

Pasar baru Karawang merupakan salah satu pasar yang berada di Kota Karawang tepatnya di ujung Jalan Tuparev No. 21-85 Nagasari Kec. Karawang Barat berdekatan dengan masjid Agung Karawang. Pasar tersebut merupakan pasar tradisional yang didirikan tahun 1950 berskala cukup besar dengan jumlah kios permanen dan non permanen kurang lebih 250 kios sehingga menjadi salah satu pusat perputaran ekonomi bagi masyarakat Kota Karawang dan 
sekitarnya mencakup Kecamatan Telukjambe Timur, Telukjambe Barat, Karawang Barat, dan Karawang Timur. Secara umum kondisi pasar cukup ramai dipadati pedagang maupun pembeli yang bertransaksi dari pagi sampai dengan pagi lagi khususnya kios sayuran dan kelontong beroperasi 24 jam. Sebagai ciri khas pasar tradisional, transaksi yang terjadi antara pedagang dan pembeli selalu melalui proses tawarmenawar terlebih dahulu.

Barang-barang yang diperjualbelikan di pasar ini mencakup pakaian, makanan ringan, kue basah, sayuran, buah-buahan, bumbu dapur, peralatan rumah tangga dan daging. Pemasok pun berasal dari luar kota Berdasarkan hasil observasi lapangan, salah satu barang yang cukup digemari pembeli adalah daging ayam. Para pedagang ayam tersebar hampir merata di seluruh area pasar dengan kios permanen ataupun non permanen. Bobot ayam utuh yang diperjualbelikan berkisar $1,2 \mathrm{~kg}$ sampai dengan $2,5 \mathrm{~kg}$ dengan kondisi tanpa bulu dan jeroan dengan harga yang beragam.

Akses yang mudah dan banyak moda transportasi menuju pasar ini, menjadikan Pasar baru Karawang sebagai pusat belanja bagi masyarakat Kabupaten Karawang dan sekitarnya baik untuk konsumsi pribadi atau untuk diperjualbelikan kembali. Kelengkapan produk yang diperjualbelikan dan harya yang mayoritas dapat ditawar menjadi daya tarik tersendiri bagi para pengunjung. Selain itu pula, 15 pada masa pandemic covid-19 ini, Pasar baru Karawang ditunjuk oleh pemerintah Kabupaten Karawang sebagai pasar percontohan diterapkannya jualbeli sehat dengan mematuhi protokol Kesehatan diantaranya dengan memakai masker dan menjaga jarak.

\section{Aktivitas Supply Chain Daging Ayam}

Berdasarkan pengamatan di lapangan aktivitas dan peran dalam kaitannya dengan rantai pasok daging ayam di pasar baru Karawang adalah sebagai berikut:

1. Supplier/pemasok

Para pemasok ini ada yang memiliki peternakan sendiri adapula yang hanya menjual tanpa beternak. Secara umum proses produksi yang dilakukan para pemasok adalah sama yaitu:

a. Melakukan proses pembibitan (jika merupakan peternak)

Perawatan yang baik diperlukan untuk menunjang pertumbuhan bibit menjadi ayam dewasa yang siap panen. Perawatan yang dimaksud meliputi pemberian pakan dan minum yang cukup, kebersihan kendang, vaksinasi terhadap berbagai penyakit dan pemberian berbagai vitamin. Pemberian pakan merupakan hal yang paling utama dalam ternak ayam pedaging beberapa peternak menerapkan sistem pakan tanpa batasan (selalu tersedia). Umur ayam yang siap panen antara 1 sd 2 bulan. Ayam 
negeri/broiler rentan terhadap stress, kebisingan dan suhu, oleh karena itu hal tersebut menjadi tantangan yang tidak mudah bagi para peternak.

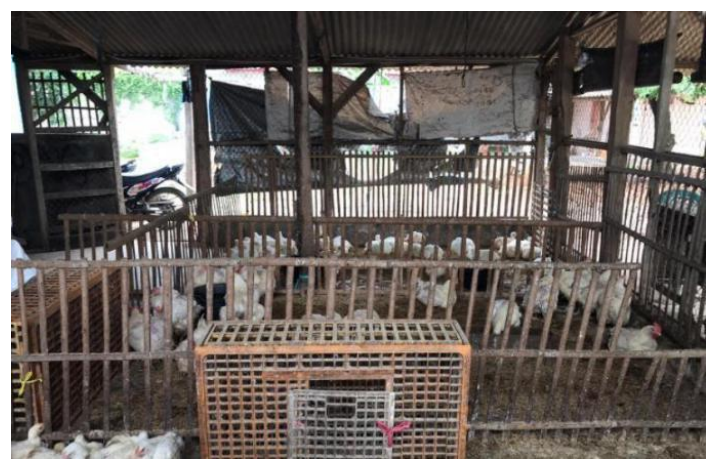

Gambar 3. Kondisi Kandang di Salah Satu Peternakan di Desa Telagasari

b. Melakukan proses penyembelihan

Proses penyembelihan adalah proses yang sangat penting dalam penentuan halal-haram daging ayam yang dihasilkan. Adapun proses penyembelihan ayam sampai dengan pembubutan yang dilakukan secara berurutan adalah sebagai berikut:

1) Ayam diambil dari kandang.

2) Ayam ditimbang per 5 ekor

3) Ayam disembelih

Setelah ditimbang, proses selanjutnya adalah penyembelihan. Proses ini merupakan proses yang paling krusial dalam penentuan kehalalan daging yang dihasilkan dari proses penyembelihan. Jika proses penyembelihan sesuai dengan syariat maka dapat dipastikan daging yang dihasilkan dijamin kehalalannya secara dzati. Daging yang secara dzati sudah diketegorikan halal ini kemudian dikontrol agar tidak tercampur dengan bahan lain yang dapat merubah status kehalalan daging tersebut. Proses ini dilakukan secara manual (tidak menggunakan mesin) terhadap satu per satu ekor ayam.

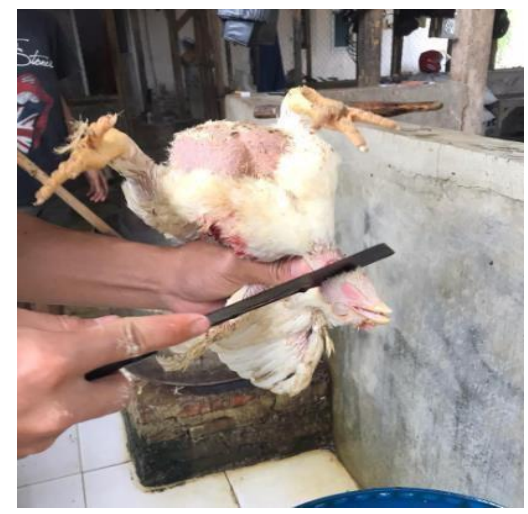

Gambar 1. Proses Penyembelihan Ayam di Salah Satu Peternakan Desa Telagasari 
4) Ayam dimasukkan ke dalam drum menunggu mati

5) Ayam dimasukkan ke dalam air panas

Proses selanjutnya adalah perebusan ayam yang sudah mati kedalam air mendidih selama kurang lebih 1 sampai dengan 2 menit. Hal ini dimaksudkan agar pada saat perontokan, bulu ayam dapat dengan mudah rontok.

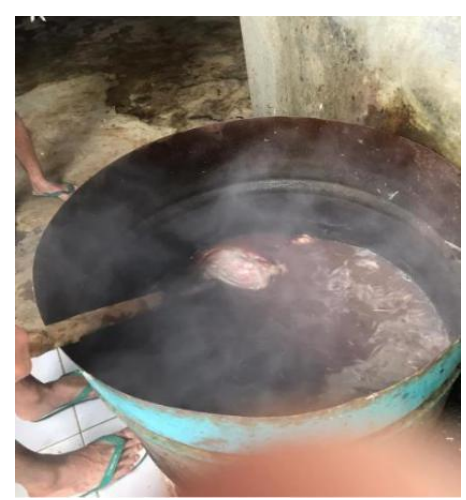

Gambar 2. Ayam Direbus pada Air Mendidih

6) Ayam dimasukkan ke dalam mesin pembubutan bulu

Setelah direbus, ayam yang telah disembelih dimasukkan ke dalam mesin perontok bulu ayam sebagaimana terlihat dalam gambar dibawah ini.

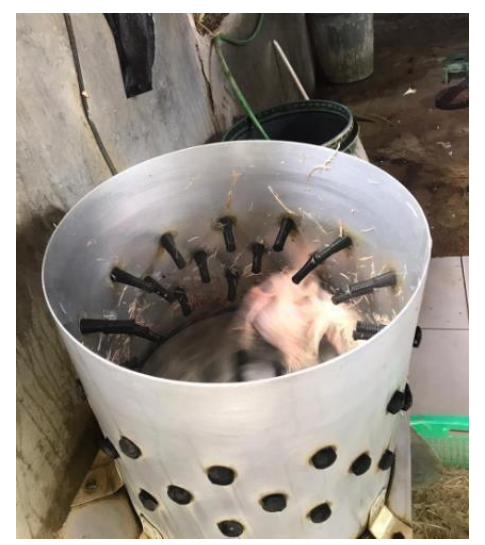

Gambar 3. Proses Perontokan Bulu Ayam

7) Daging ayam dimasukkan ke dalam wadah siap dikirim

2. Pedagang pasar

Dari pemasok, daging ayam kemudian dijajakan di pasar oleh para pedagang pasar yang tersebar di seluruh area pasar. Jeroan ayam biasanya dijual terpisah dengan daging murni dan harganya lebih murah dari pada daging murni. Para pedagang tersebut ada yang mempunyai kios permanen ada yang hanya di emperan (tidak permanen). Kondisi daging ayam yang dipajang mayoritas dengan posisi tiduran dan terbuka tanpa penutup dan kadang dihinggapi lalat. Ada beberapa juga yang memajang dengan cara menggantungkan daging 
ayam tersebut. Pedagang daging ayam mayoritas memfokuskan dagangannya pada daging ayam saja tanpa berjualan jenis daging yang lain. Hal ini membuat sangat kecil sekali kemungkinan danging ayam bersentuhan dengan daging yang jelas tidak halal seperti daging babi, daging anjing, misalnya. Konsumen dari pedagang pasar ini adalah para pedagang sayur kecil/keliling ataupun konsumen akhir yang akan mengkonsumsi sendiri daging ayam tersebut. Kebanyakan yang berbelanja daging ayam adalah para wanita dan sering sekali terjadi proses tawar menawar yang wajar terjadi di pasar tradisional.

3. Pedagang sayur kecil/keliling

Rantai berikutnya yang terdapat pada supply chain daging ayam di pasar baru karawang adalah para pedagang sayur kecil/keliling. Mereka membeli daging ayam di pasar untuk kemudian dijual kembali kepada konsumen rumah tangga sebagai konsumen akhir. Para pedagang sayur ini ada yang mempunyai kios permanen ada yang dengan cara berkeliling dari suatu tempat ke tempat (pemukiman) yang lain. Kondisi daging ayam yang dijualbelikan di tukang sayur biasanya dimasukkan ke dalam wadah pendingin baik dengan listrik ataupun dengan sistem manual (batu es) dicampur dengan jenis daging yang lain seperti daging sapi dan ikan. Hal ini dilakukan agar daging tahan lama dan terlihat segar.

4. Konsumen akhir

Rantai terakhir yang ada pada rantai supply daging ayam pasar baru Karawang adalah para ibu rumah tangga sebagai konsumen akhir. Mayoritas ibu rumah tangga berbelanja pada tukang sayur kecil/keliling dari pada langsung ke pasar. Meskipun beberapa mereka juga lebih menyukai berbelanja langsung ke pasar karena alasan harganya yang lebih murah. Bagi mereka yang berbelanja langsung ke pasar biasanya akan membeli dalam porsi yang agak banyak untuk disimpan selama beberapa hari sampai dengan satu minggu di dalam lemari es. Sedangkan bagi yang membeli daging ayam kepada tukang sayur kecil/keliling biasanya hanya untuk keperluan memasak 1 sampai dengan 2 hari saja. Sebelum dimasak biasanya daging ayam dipotong-potong menjadi bagian- bagian lebih kecil sesuai kebutuhan dan dicuci terlebih dahulu untuk menghilangkan kotoran-kotoran yang menempel pada daging ayam.

Dari uraian di atas, meskipun pada beberapa kasus ditemukan kenyataan yang berbeda, namun secara umum dapat disimpulkan bahwa unsur-unsur yang terlibat di dalam proses supply chain daging ayam di pasar baru Karawang sebagai berikut: 


\begin{tabular}{|c|c|c|c|}
\hline $\begin{array}{l}\text { Pemasok/ } \\
\text { Peternak }\end{array}$ & $\begin{array}{l}\text { Pedagang } \\
\text { Pasar }\end{array}$ & $\begin{array}{l}\text { Tukang } \\
\text { Sayur }\end{array}$ & $\begin{array}{l}\text { Konsumen } \\
\text { Akhir/IRT }\end{array}$ \\
\hline
\end{tabular}

Gambar 3. Unsur Supply Chain Perdagangan Daging Ayam Pasar Baru

Dengan demikian, dalam konsepsi halal supply chain management, proses-proses baik proses produksi maupun logistik yang ada dalam keempat unsur di atas kaitannya denganpengolahan dan penanganan daging ayam harus sesuai dengan kaidah syariat islam yaitu halal dan thoyyib (baik).

\section{Analisis Implementasi Halal Supply Chain}

Dilakukan survey terhadap keempat unsur yang terlibat dalam supply chain daging ayam mengenai kesadaran dan pemahaman mereka tentang pentingnya mengkonsumsi daging ayam yang dipastikan kelalalannya.Jumlah responden pemasok adalah seluruh pemasok yang memasok daging ayam di pasar baru Karawang yang berjumlah 7 pemasok tersebar di Kec. Telagasari dan Kec. Majalaya. Jumlah responden pedagang adalah seluruh pedagang yang berjualan daging ayam di pasar baru Karawang yang berjumlah 24 pedagang. Sedangkan jumlah total tukang sayur yang menjadi pelanggan baik yang mempunyai kios permanen ataupun tukang sayur keliling berjumlah 155 orang. Berdasarkan rumus slovin dan dengan menggunakan taraf signifikansi 10\%, maka jumlah sample yang dapat diambil untuk responden tukang sayur adalah:

Jumlah sample $=155 /\left(1+155^{*} 0,05^{2}\right)=60,8$ dibulatkan 61 pedagang sayur

Sedangkan jumlah populasi konsumen akhir tidak diketahui sehingga dapat dianggap populasi tak hingga. Oleh karena itu, pengambilan sample dilakukan dengan teknik sampling insidental yakni teknik pengambilan sample sacara kebetulan bertemu/sedang melakukan transaksi. Sehingga jumlah sampel dari populasi tak hingga diambil mengikuti rumus Lameshow:

Jumlah sample $=\left(1,96^{2} * 0,5(1-0,5)\right) /\left(0,1^{2}\right)=96,04$ orang dibulatkan 97 orang 


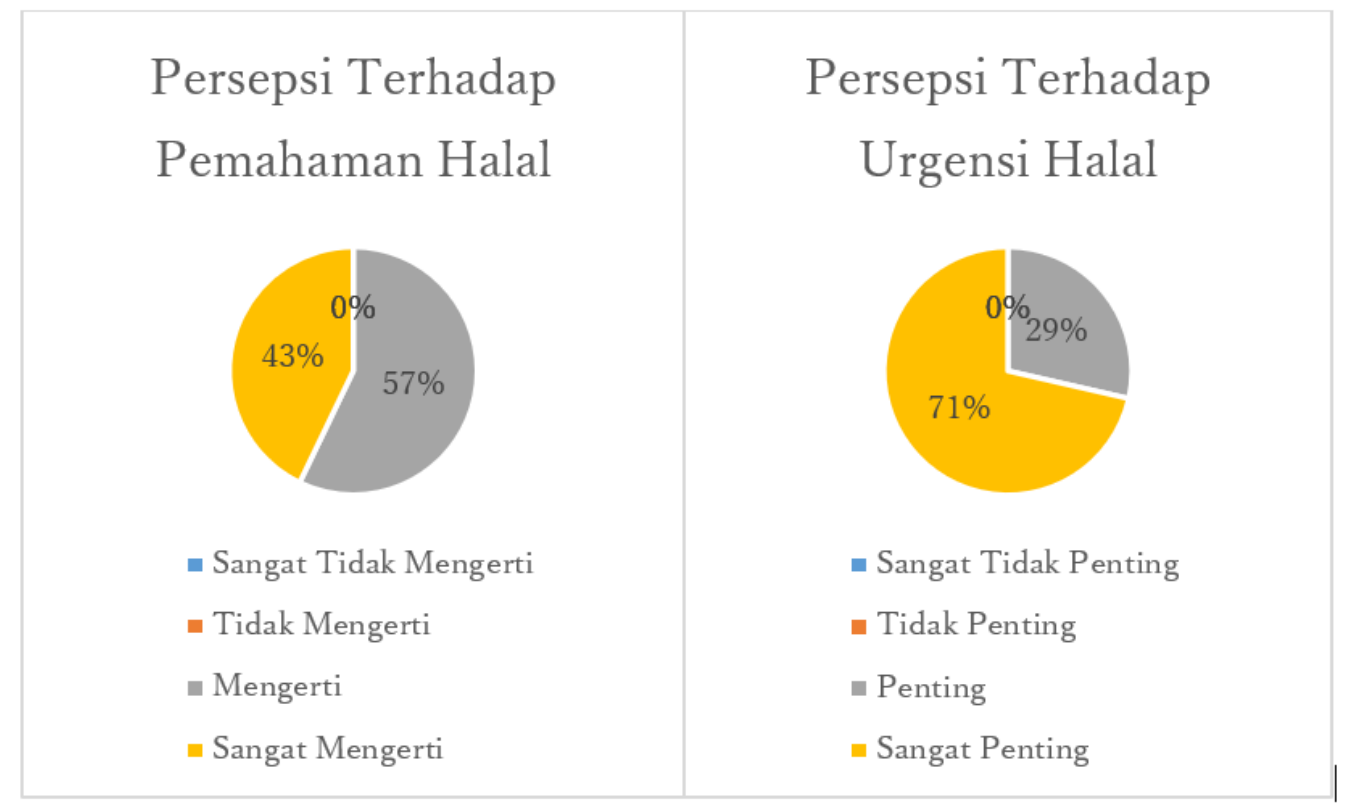

Gambar 4. Hasil Kuesioner Persepsi Pemasok

\begin{tabular}{|c|c|}
\hline Persepsi Terhadap & Persepsi Terhadap \\
\hline Pemahaman Halal & Urgensi Halal \\
\hline $29 \%$ & \\
\hline - Sangat Tidak Mengerti & - Sangat Tidak Penting \\
\hline - Tidak Mengerti & - Tidak Penting Legend \\
\hline - Mengerti & = Penting \\
\hline = Sangat Mengerti & = Sangat Penting \\
\hline
\end{tabular}

Gambar 5. Hasil Kuesioner Persepsi Pedagang Pasar 
Persepsi Terhadap

Pemahaman Halal

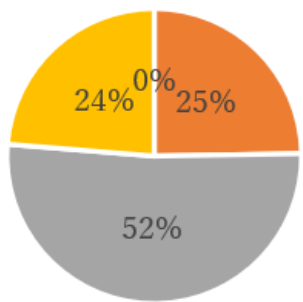

- Sangat Tidak Mengerti

- Tidak Mengerti

- Mengerti

n Sangat Mengerti
Persepsi Terhadap

Urgensi Halal

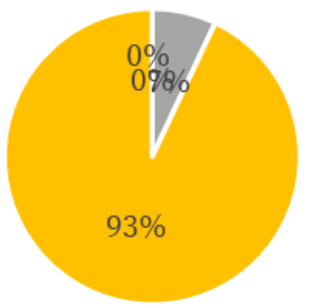

- Sangat Tidak Penting

- Tidak Penting

- Penting

n Sangat Penting

Gambar 6. Hasil Kuesioner Persepsi Pedagang Sayur

\begin{tabular}{|l|c|}
\hline $\begin{array}{l}\text { Persepsi Terhadap } \\
\text { Pemahaman Halal }\end{array}$ & $\begin{array}{c}\text { Persepsi Terhadap } \\
\text { Urgensi Halal }\end{array}$ \\
\hline & \\
\hline $52 \%$ & \\
\hline &
\end{tabular}

Gambar 7. Hasil Kuesioner Persepsi Konsumen Akhir 
Dari dari data-data di atas dapat disimpulkan bahwa mayoritas pemasok, pedagang pasar, pedagang sayur, dan konsumen akhir mengerti konsepsi halal produk daging ayam meskipun adabeberapa saja yang menyatakan tidak mengerti. Begitupun mayoritas dari mereka khususnya para konsumen akhir menyadari pentingnya jaminan halal terhadap produk daging ayam yang ada di pasaran. Khusus bagi konsumen akhir walaupun sebanyak 25\% tidak mengerti bagaimana konsepsi halal diterapkan pada produk daging ayam, akan tetapi mayoritas berpendapat bahwa jaminan halal sangat penting adanya agar membuat para konsumen akhir menjadi nyaman dan hati tenang karena telah melaksanakan syariat islam.

Hal selanjutnya adalah analisis ini hanya berdasarkan observasi secara kasat mata tidak dimaksudkan untuk menjamin secara syar'i 100\% terhadap kehalalan daging tersebut. Berikut adalah tabel analisis terhadap implementasi halal supply chain dari daging ayam yang diperdagangkan di setiap proses pada masing-masing unsur supply chain dari 3 pemasok daging ayam:

Tabel 1. Analisis terhadap Implementasi Halal Supply Chain

\begin{tabular}{|c|c|c|c|c|}
\hline No & Syarat Syar'i & Referensi/Dasar & Hasil Observasi & Kesimpulan \\
\hline \multicolumn{5}{|c|}{ PADA UNSUR PEMASOK } \\
\hline 1 & $\begin{array}{l}\text { Manajemen puncak harus } \\
\text { menunjukkan } \\
\text { kepemimpinan dan } \\
\text { komitmen terhadap sistem } \\
\text { manajemen halal }\end{array}$ & $\begin{array}{l}\text { SNI 99001:2016 } \\
\text { tentang Sistem } \\
\text { Manajemen } \\
\text { Halal }\end{array}$ & $\begin{array}{l}\text { Hasil wawancara kepada } \\
\text { pemilik, semuanya } \\
\text { mempunyai komitmen } \\
\text { yang kuat terhadap } \\
\text { kehalalan daging ayam } \\
\text { yang dihasilkan }\end{array}$ & $\begin{array}{l}\text { Ketiganya memenuhi } \\
\text { syarat }\end{array}$ \\
\hline 2 & $\begin{array}{l}\text { penyelia halal harus } \\
\text { beragama Islam dan } \\
\text { memiliki wawasan luas dan } \\
\text { memahami syariat tentang } \\
\text { kehalalan }\end{array}$ & $\begin{array}{l}\text { SNI 99001:2016 } \\
\text { tentang Sistem } \\
\text { Manajemen } \\
\text { Halal }\end{array}$ & $\begin{array}{l}\text { Hasil wawancara kepada } \\
\text { pemilik, semua pemilik } \\
\text { beragama islam dan cukup } \\
\text { memahami kehalalan } \\
\text { daging }\end{array}$ & $\begin{array}{l}\text { Ketiganya memenuhi } \\
\text { syarat }\end{array}$ \\
\hline 3 & $\begin{array}{l}\text { Penyediaan pakan, minum, } \\
\text { vaksin, dan vitamin yang } \\
\text { dikonsumsi ternak dari } \\
\text { terbuat bahan yang baik } \\
\text { lagi halal }\end{array}$ & $\begin{array}{l}\text { SNI 99001:2016 } \\
\text { tentang Sistem } \\
\text { Manajemen } \\
\text { Halal }\end{array}$ & $\begin{array}{l}\text { Hasil observasi dilapangan } \\
\text { pakan, minum, vaksin, dan } \\
\text { vitamin yang digunakan } \\
\text { mempunyai izin edar, } \\
\text { namun belum bisa } \\
\text { dipastikan kehalalannya } \\
100 \%\end{array}$ & $\begin{array}{l}\text { Jika } \\
\text { terjadi perubahan warna, } \\
\text { aroma, dan rasanya maka } \\
\text { harus dikarantina terlebih } \\
\text { dahulu sampai normal. } \\
\text { (sumber: } \\
\text { http://www.halalmui.org/) } \\
\text { Kenyataan dilapangan } \\
\text { ketiganya tidak ada } \\
\text { perubahan warna, aroma } \\
\text { dan rasanya }\end{array}$ \\
\hline
\end{tabular}




\begin{tabular}{|c|c|c|c|c|}
\hline 4 & $\begin{array}{l}\text { Lingkungan/kondisi } \\
\text { kandang ternak bersih dan } \\
\text { jauh dari cemaran barang- } \\
\text { barang yang berbahaya }\end{array}$ & $\begin{array}{l}\text { SNI 99001:2016 } \\
\text { tentang Sistem } \\
\text { Manajemen } \\
\text { Halal }\end{array}$ & $\begin{array}{l}\text { Hasil observasi di lapangan } \\
\text { kandang dibersihkan dan } \\
\text { disemprot desinfektan } \\
\text { secara berkala, dan jauh } \\
\text { dari barang-barang yang } \\
\text { berbahaya/pencemaran }\end{array}$ & $\begin{array}{l}\text { Ketiganya memenuhi } \\
\text { syarat }\end{array}$ \\
\hline 5 & $\begin{array}{l}\text { Penyembelihan dilakukan } \\
\text { oleh juru sembelih halal } \\
\text { yang memahami proses } \\
\text { penyembelihan sesuai } \\
\text { dengan kaidah } \\
\text { kesejahteraan hewan dan } \\
\text { syariat Islam }\end{array}$ & $\begin{array}{l}\text { SNI 99002:2016 } \\
\text { tentang } \\
\text { Pemotongan } \\
\text { Halal pada } \\
\text { Unggas }\end{array}$ & $\begin{array}{l}\text { Hasil wawancara, } \\
\text { menunjukkan bahwa juru } \\
\text { sembelih memahami } \\
\text { proses penyembelihan } \\
\text { sesuai dengan kaidah } \\
\text { kesejahteraan hewan dan } \\
\text { syariat Islam }\end{array}$ & $\begin{array}{l}\text { Ketiganya memenuhi } \\
\text { syarat }\end{array}$ \\
\hline 6 & $\begin{array}{l}\text { Juru sembelih HARUS } \\
\text { beragama Islam, dewasa } \\
\text { (baligh) dan berakal sehat }\end{array}$ & $\begin{array}{l}\text { SNI 99002:2016 } \\
\text { tentang } \\
\text { Pemotongan } \\
\text { Halal pada } \\
\text { Unggas }\end{array}$ & $\begin{array}{l}\text { Hasil wawancara, juru } \\
\text { sembelih beragama islam } \\
\text { dewasa (baligh) dan } \\
\text { berakal sehat }\end{array}$ & $\begin{array}{l}\text { Ketiganya memenuhi } \\
\text { syarat }\end{array}$ \\
\hline 7 & $\begin{array}{l}\text { Ayam yang akan } \\
\text { disembelih harus dalam } \\
\text { keadaan Sehat dan bersih } \\
\text { untuk mencegah penularan } \\
\text { penyakit akibat } \\
\text { mengkonsumsi ayam yang } \\
\text { sakit }\end{array}$ & $\begin{array}{l}\text { SNI 99002:2016 } \\
\text { tentang } \\
\text { Pemotongan } \\
\text { Halal pada } \\
\text { Unggas }\end{array}$ & $\begin{array}{l}\text { Secara fisik berdasarkan } \\
\text { observasi, ayam yang } \\
\text { disembelih terlihat segar. } \\
\text { Selain itu ada proses } \\
\text { seleksi bagi ayam yang } \\
\text { terlihat sakit, dipisahkan } \\
\text { dari yang lainnya. Namun } \\
\text { memang tidak dicek secara } \\
\text { detail pada skala } \\
\text { laboratorium }\end{array}$ & $\begin{array}{l}\text { Ketiganya memenuhi } \\
\text { syarat }\end{array}$ \\
\hline 8 & $\begin{array}{l}\text { Proses penyembelihan } \\
\text { disunnahkan menghadap } \\
\text { kiblat }\end{array}$ & $\begin{array}{l}\text { SNI 99002:2016 } \\
\text { tentang } \\
\text { Pemotongan } \\
\text { Halal pada } \\
\text { Unggas }\end{array}$ & $\begin{array}{l}\text { Satu diantara pemasok } \\
\text { menyembelih hanya } \\
\text { dengan sendiri dan ayam } \\
\text { dihadapkan ke arah atas. }\end{array}$ & $\begin{array}{l}\text { Hanya satu pemasok yang } \\
\text { tidak memenuhi syarat, } \\
\text { namun ini hanya } \\
\text { disunahkan }\end{array}$ \\
\hline 9 & $\begin{array}{l}\text { Sebelum menyembelih, } \\
\text { Juru sembelih melafazkan } \\
\text { "bismillahi allahuakbar" } \\
\text { atau } \\
\text { "bismillahirrahmanirahiim" }\end{array}$ & $\begin{array}{l}\text { SNI 99002:2016 } \\
\text { tentang } \\
\text { Pemotongan } \\
\text { Halal pada } \\
\text { Unggas }\end{array}$ & $\begin{array}{l}\text { Para penyembelih } \\
\text { terdengar mengucapkan } \\
\text { "bismillahirrahmanirahiim" } \\
\text { walau dengan nada pelan }\end{array}$ & $\begin{array}{l}\text { Ketiganya memenuhi } \\
\text { syarat }\end{array}$ \\
\hline 10 & $\begin{array}{l}\text { Penyembelihan dilakukan } \\
\text { pada pangkal leher unggas } \\
\text { dengan memutuskan } \\
\text { saluran pernafasan } \\
\text { (trakhea/hulqum), saluran } \\
\text { makan (esofagus/mari') } \\
\text { dan dua urat lehernya } \\
\text { (pembuluh darah di kanan } \\
\text { dan kiri leher/wadajain) } \\
\end{array}$ & $\begin{array}{l}\text { SNI 99002:2016 } \\
\text { tentang } \\
\text { Pemotongan } \\
\text { Halal pada } \\
\text { Unggas }\end{array}$ & $\begin{array}{l}\text { Para penyembelih } \\
\text { melakukan penyembelihan } \\
\text { dengan memutuskan } \\
\text { saluran pernafasan } \\
\text { (trakhea/hulqum), saluran } \\
\text { makan (esofagus/mari') } \\
\text { dan dua urat lehernya } \\
\text { (pembuluh darah di kanan } \\
\text { dan kiri leher/wadajain) }\end{array}$ & $\begin{array}{l}\text { Ketiganya memenuhi } \\
\text { syarat }\end{array}$ \\
\hline
\end{tabular}




\begin{tabular}{|c|c|c|c|c|}
\hline 11 & $\begin{array}{l}\text { Penyembelihan dilakukan } \\
\text { dengan sekali sayatan } \\
\text { tanpa mengangkat pisau }\end{array}$ & $\begin{array}{l}\text { SNI 99002:2016 } \\
\text { tentang } \\
\text { Pemotongan } \\
\text { Halal pada } \\
\text { Unggas } \\
\end{array}$ & $\begin{array}{l}\text { Para penyembelih } \\
\text { melakukan penyembelihan } \\
\text { dengan sekali sayatan } \\
\text { tanpa mengangkat pisau }\end{array}$ & $\begin{array}{l}\text { Ketiganya memenuhi } \\
\text { syarat }\end{array}$ \\
\hline 12 & $\begin{array}{l}\text { Proses penyembelihan } \\
\text { dilakukan dari leher bagian } \\
\text { depan dan tidak memutus } \\
\text { tulang leher. }\end{array}$ & $\begin{array}{l}\text { SNI 99002:2016 } \\
\text { tentang } \\
\text { Pemotongan } \\
\text { Halal pada } \\
\text { Unggas }\end{array}$ & $\begin{array}{l}\text { Hasil observasi terlihat, } \\
\text { leher ayam tidak putus }\end{array}$ & $\begin{array}{l}\text { Ketiganya memenuhi } \\
\text { syarat }\end{array}$ \\
\hline 13 & $\begin{array}{l}\text { Darah ayam dibiarkan } \\
\text { keluar dengan waktu } \\
\text { minimal } 3 \text { menit sebelum } \\
\text { proses berikutnya (lebih } \\
\text { baik dalam posisi } \\
\text { digantung untuk } \\
\text { memaksimalkan } \\
\text { pengeluaran darah) }\end{array}$ & $\begin{array}{l}\text { SNI 99002:2016 } \\
\text { tentang } \\
\text { Pemotongan } \\
\text { Halal pada } \\
\text { Unggas }\end{array}$ & $\begin{array}{l}\text { Ayam yang dipotong } \\
\text { dimasukkan kedalam tong } \\
\text { dan langsung dimasukkan } \\
\text { ke dalam proses perebusan } \\
\text { tanpa menunggu } 3 \text { menit } \\
\text { atau memastikan ayam } \\
\text { telah mati. Namun dapat } \\
\text { dilihat bahwa ayam sudah } \\
\text { tidak bergerak-gerak } \\
\end{array}$ & $\begin{array}{l}\text { Perlu pemastian atau } \\
\text { menunggu rekomendasi } 3 \\
\text { menit. Namun terlihat } \\
\text { secara kasat mana ayam } \\
\text { sudah tidak bergerak, } \\
\text { dengan demikian } \\
\text { memenuhi syarat }\end{array}$ \\
\hline 14 & $\begin{array}{l}\text { Proses } \\
\text { pengiriman/distribusi tidak } \\
\text { tercampur dengan } \\
\text { barang/benda non halal }\end{array}$ & $\begin{array}{l}\text { SNI 99001:2016 } \\
\text { tentang Sistem } \\
\text { Manajemen } \\
\text { Halal }\end{array}$ & $\begin{array}{l}\text { Pengiriman tidak dicampur } \\
\text { dengan bahanataupun } \\
\text { daging yang lain }\end{array}$ & $\begin{array}{l}\text { Ketiganya memenuhi } \\
\text { syarat }\end{array}$ \\
\hline 15 & $\begin{array}{l}\text { Tidak diperbolehkan } \\
\text { mengurangi timbangan dari } \\
\text { yang semestinya }\end{array}$ & $\begin{array}{l}\text { QS. al- } \\
\text { Muthaffifîn ayat } \\
1-6\end{array}$ & $\begin{array}{l}\text { Hasil observasi secara } \\
\text { langsung, tidak ditemukan } \\
\text { indikasi mengurangi } \\
\text { timbangan tapi tetap perlu } \\
\text { dilakukan kalibrasi }\end{array}$ & $\begin{array}{l}\text { Ketiganya memenuhi } \\
\text { syarat namun untuk } \\
\text { pemastian diperlukan } \\
\text { kalibrasi }\end{array}$ \\
\hline \multicolumn{5}{|c|}{ PADA UNSUR PEDAGANG PASAR } \\
\hline 16 & $\begin{array}{l}\text { Penyajian/display/wadah } \\
\text { daging ayam dipastikan } \\
\text { tidak tercampur dengan } \\
\text { barang/benda non halal }\end{array}$ & $\begin{array}{l}\text { SNI 99001:2016 } \\
\text { tentang Sistem } \\
\text { Manajemen } \\
\text { Halal } \\
\end{array}$ & $\begin{array}{l}\text { Penyajian/wadah tidak } \\
\text { tercampur dengan } \\
\text { barang/daging lain }\end{array}$ & Memenuhi syarat \\
\hline 17 & $\begin{array}{l}\text { Daging ayam kondisinya } \\
\text { segar, tidak busuk dan } \\
\text { berbau tidak sedap }\end{array}$ & $\begin{array}{l}\text { QS. Al-Baqarah } \\
\text { ayat } 168\end{array}$ & $\begin{array}{l}\text { Daging ayam yang dijual } \\
\text { masih segar (sembelihan di } \\
\text { hari yang sama) }\end{array}$ & Memenuhi syarat \\
\hline 18 & $\begin{array}{l}\text { Tidak diperbolehkan } \\
\text { mengurangi timbangan dari } \\
\text { yang semestinya }\end{array}$ & $\begin{array}{l}\text { QS. al- } \\
\text { Muthaffifîn ayat } \\
1-6\end{array}$ & $\begin{array}{l}\text { Hasil observasi secara } \\
\text { langsung, tidak ditemukan } \\
\text { indikasi mengurangi } \\
\text { timbangan tapi tetap perlu } \\
\text { dilakukan kalibrasi }\end{array}$ & $\begin{array}{l}\text { Memenuhi syarat namun } \\
\text { untuk pemastian } \\
\text { diperlukan kalibrasi }\end{array}$ \\
\hline \multicolumn{5}{|c|}{ PADA UNSUR PEDAGANG SAYUR } \\
\hline 16 & $\begin{array}{l}\text { Penyajian/display/wadah } \\
\text { daging ayam dipastikan }\end{array}$ & $\begin{array}{l}\text { SNI 99001:2016 } \\
\text { tentang Sistem }\end{array}$ & $\begin{array}{l}\text { Penyajian/wadah dengan } \\
\text { barang/daging lain yakni } \\
\text { daging ikan }\end{array}$ & $\begin{array}{l}\text { Memenuhi syarat karena } \\
\text { ikan merupakan daging }\end{array}$ \\
\hline
\end{tabular}




\begin{tabular}{|r|l|l|l|l|}
\hline 17 & $\begin{array}{l}\text { tidak tercampur dengan } \\
\text { barang/benda non halal }\end{array}$ & $\begin{array}{l}\text { Manajemen } \\
\text { Halal }\end{array}$ & $\begin{array}{l}\text { yang tidak perlu } \\
\text { disembelih }\end{array}$ \\
\hline $\begin{array}{l}\text { segar, tidak busuk dan } \\
\text { berbau tidak sedap }\end{array}$ & $\begin{array}{l}\text { QS. Al-Baqarah } \\
\text { ayat 168 }\end{array}$ & $\begin{array}{l}\text { Daging ayam yang dijual } \\
\text { masih segar (sembelihan di } \\
\text { hari yang sama) atau } \\
\text { biasanya maksimal sampai } \\
\text { dengan hari berikutnya }\end{array}$ & $\begin{array}{l}\text { Memenuhi syarat } \\
\text { berdasarkan } \\
\text { doktersehat.com lama } \\
\text { penyimpanan daging } \\
\text { ayam di tempat dingin } \\
\text { maksimal 2 hari }\end{array}$ \\
\hline 18 & $\begin{array}{l}\text { Tidak diperbolehkan } \\
\text { mengurangi timbangan dari } \\
\text { yang semestinya }\end{array}$ & $\begin{array}{l}\text { QS. al- } \\
\text { Muthaffifin ayat at and } \\
1-6\end{array}$ & $\begin{array}{l}\text { Hasil observasi secara } \\
\text { langsung, tidak ditemukan } \\
\text { indikasi mengurangi } \\
\text { timbangan tapi tetap perlu } \\
\text { dilakukan kalibrasi }\end{array}$ & $\begin{array}{l}\text { Memenuhi syarat namun } \\
\text { untuk pemastian } \\
\text { diperlukan kalibrasi }\end{array}$ \\
\hline
\end{tabular}

Dari tabel di atas dapat disimpulkan bahwa peranan yang paling menentukan dalam kehalalan daging ayam adalah dari sisi pemasok karena pada pemasok terdapat proses penyembelihan yang merupakan proses yang paling krusial dalam penentuan kehalalan daging ayam secara dzati. Dari tabel di atas pula dapat disimpulkan bahwa dari ketiga pemasok daging ayam ke pasar baru karawang secara umum berdasarkan observasi secara langsung di lapangan sudah memenuhi syarat syar'i mengenai kehalalan daging ayam dan sampai kepada konsumen akhir tidak terkontaminasi dengan barang haram/najis. Akan tetapi tetap masih diperlukan penyempurnaan sebagai berikut:

1. Pada penyediaan pakan dan lain-lain perlu dipastikan kembali kehalalan bahan dari makanan, minuman, vaksin, dan vitamin meskipun tidak secara langsung mempengaruhi daging ayam tersebut hal ini demi menghindari perkara yang syubhat.

2. Perlu adanya pemastian untuk satu pemasok dalam hal penyembelihan disunahkan menghadap kiblat. Meskipun hal tersebut hanya bersifat sunnah, namun sangat besar sekali manfaatnya dan sebenarnya hal tersebut ringan dikerjakan. Oleh karena itu, untuk kesempurnaan penyembelihan, pemilik harus memberikan edukasi kembali terhadap para juru sembelih tersebut.

3. Perlu adanya pemastian bahwa ayam yang disembelih sudah betul-betul mati sebelum proses selanjutnya. Menurut standar SNI, waktu yang direkomendasikan setidaknya 3 menit menunggu ayam benar-benar mati. Hal ini agar dapat dipastikan bahwa ayam mati karena sebab disembelih bukan sebab yang lain. Sehingga jika ayam yang belum benar-benar mati kemudian langsung direbus, bisa jadi kematiannya bukan karena penyembelihan melainkan karena panasnya air rebusan. Oleh karena itu, untuk menghindari syubhat pemilik harus 
memberikan edukasi kepada para juru sembelih mengenai hal demikian.

\section{Analisis Risiko}

Analisis resiko yang dimaksud adalah analisis terhadap implementasi konsep halal supply chain sehingga produk yang seharusnya halal dikhawatirkan menjadi haram karena faktor kesalahan ataupun ketidaktahuan orang-orang yang berperan dalam rantai pasokan daging ayam tersebut. Adapun analisis resiko menjadi haram dijelaskan dalam tabel berikut:

Tabel 2. Peta Risiko Kehalalan Daging Ayam

\begin{tabular}{|l|l|l|l|}
\hline No & Aktivitas Berisiko & Level Risiko & Peanggulangan \\
\hline 1 & $\begin{array}{l}\text { Penyembelihan tidak } \\
\text { menghadap kiblat }\end{array}$ & Resiko Sedang & $\begin{array}{l}\text { Edukasi, } \\
\text { standarisai }\end{array}$ \\
\hline 2 & $\begin{array}{l}\text { Ayam belum mati Ketika proses } \\
\text { perebusan }\end{array}$ & Resiko tinggi & $\begin{array}{l}\text { Edukasi, } \\
\text { standarisari }\end{array}$ \\
\hline 3 & $\begin{array}{l}\text { Daging ayam tercampur dengan } \\
\text { bahan haram/najis }\end{array}$ & Resiko rendah & $\begin{array}{l}\text { Edukasi, } \\
\text { standarisari }\end{array}$ \\
\hline 4 & Timbangan tidak sesuai & Resiko rendah & $\begin{array}{l}\text { Kalibrasi secara } \\
\text { berkala }\end{array}$ \\
\hline
\end{tabular}

\section{KESIMPULAN}

Adapun kesimpulan yang dapat ditarik dari penelitian ini adalah:

1. Ketiga pemasok daging ayam ke pasar baru karawang secara umum berdasarkan observasi secara langsung di lapangan sudah memenuhi syarat syar'i mengenai kehalalan daging ayam dan sampai kepada konsumen akhir tidak terkontaminasi dengan barang haram/najis. Akan tetapi tetap masih diperlukan penyempurnaan sebagai berikut:

a. Pada penyediaan pakan dan lain-lain perlu dipastikan kembali kehalalan bahan dari makanan, minuman, vaksin, dan vitamin meskipun tidak secara langsung mempengaruhi daging ayam tersebut hal ini demi menghindari perkara yang syubhat.

b. Perlu adanya pemastian untuk satu pemasok dalam hal penyembelihan disunahkan menghadap kiblat. Meskipun hal tersebut hanya bersifat sunnah, namun sangat besar sekali manfaatnya dan sebenarnya hal tersebut ringan dikerjakan. Oleh karena itu, untuk kesempurnaan penyembelihan, pemilik harus memberikan edukasi kembali terhadap para juru sembelih tersebut.

c. Perlu adanya pemastian bahwa ayam yang disembelih sudah betul-betul mati sebelum 
proses selanjutnya. Menurut standar SNI, waktu yang direkomendasikan setidaknya 3 menit menunggu ayam benar-benar mati. Hal ini agar dapat dipastikan bahwa ayam mati karena sebab disembelih bukan sebab yang lain. Sehingga jika ayam yang belum benar-benar mati kemudian langsung direbus, bisa jadi kematiannya bukan karena penyembelihan melainkan karena panasnya air rebusan. Oleh karena itu, untuk menghindari syubhat pemilik harus memberikan edukasi kepada para juru sembelih mengenai hal demikian.

2. Risiko yang dapat terjadi dikelompokkan menjadi resiko rendah, resiko sedang dan resiko tinggi. Resiko rendah yaitu daging ayam tercampur dengan bahan najis/haram dan timbangan tidak sesuai. Resiko sedang yaitu penyembelihan tidak menghadap kiblat. Sedangkan resiko tinggi yaktu ayam belum benar-benar mati karena berhubungan langsung dengan kehalalan daging ayam. Hal ini pula yang jarang disadari oleh para pemasok daging ayam mereka kebanyakan tidak memastikan benar-benar mati atau tidak menunggu setidaknya 3 menit. Oleh karena itu, dibutuh edukasi, standarisasi, serta kalibrasi timbangan bagi para pemasok dan pedagang daging ayam.

\section{DAFTAR PUSTAKA}

Badan Pusat Statistik, Laporan Hasil Survey Penduduk Tahun 2010.

Bahrudin, S.S.M., Illyas, M.I. and Desa, M.I. (2011). Tracking and tracing technology for halal product integrity over the supply chain. International Conference on Electrical Engineering and Informatics (ICEEI), Banding, pp. 1-7.

Dahlan, Abdul Aziz. (1996). Ensiklopedi Hukum Islam. Cetakan ke 1. Jakarta: Ikhtiar Baru van hoeve.

Doktersehat.com. (2019). Berapa Lama Ayam Bisa Disimpan di Lemari Pendingin. Dengan link: https://doktersehat.com/lama-ayam-bisa-disimpan/diakses pada 14 Oktober 2020.

Halalmui.org. (2019). Pemanfaatan Bahan Babi untuk Pakan Ternak. Dengan link: http://www.halalmui.org/mui14/main/detail/pemanfaatan-bahan-dari-babi-untukpakan-ternakdiaksespada 14 Oktober 2020.

Qurtubi, Kusrini E.. (2018). Research in halal logistics and halal supply chain: Issue and area development, MATEC Web of Conferences, 154.

Talib, Ab., Hamid A.B.A., Zulfakar M.H. (2015). Halal supply chain criticalsuccess factors: A literature review. Journal of Islamic Marketing, 6 (1), pp. 4471.

Tieman, M., \& Ghazali, M. C. (2012). Principles in halal supply chainmanagement. 3(3), 217-243.

Standar Nasional Indonesia. SNI 99002:2016 tentang Pemotongan Halal pada Unggas.

Standar Nasional Indonesia. SNI 99001:2016 tentang Sistem Manajemen Halal 